\title{
Project failure Indicators: perceptions of Thai and Malaysian engineers
}

\author{
Pittayaporn Gomarn ${ }^{1, *}$, and Jakrapong Pongpeng ${ }^{1}$ \\ ${ }^{1}$ Civil Engineering Department, Faculty of Engineering, King Mongkut’s Institute of Technology Ladkrabang, Bangkok, Thailand
}

\begin{abstract}
This research aims to compare the rank and importance level of failure indicators of the construction projects from the perception of Thai and Malaysian engineers. The questionnaire was used to survey the opinions of the engineers who supervised construction projects in Bangkok, Thailand and Kuala Lumpur, Malaysia. Analysis of the data was undertaken with the use of SPSS software which included a comparison of the importance level of construction project failure indicators from the perception of Thai and Malaysian engineers. Additionally, the Mann Whitney U test was used to compare the similarities and differences of construction project failure indicators from the perceptions of both Thai and Malaysian engineers. The results showed that construction project failure indicators from both Thai and Malaysian engineers were similar. Failure indicators ranked in importance were: 1) negative effects on safety, health and environment $(18.83 \%), 2)$ cost overrun $(18.44 \%), 3)$ time overruns $(17.41 \%)$, 4) quality defects $(16.43 \%), 5)$ stakeholders' dissatisfaction (15.36\%), and 6) dispute and litigation (13.54\%). The outcome of the research is therefore useful in assisting supervisory staff better understand project failure indicators. In addition, the research can be used as a guideline for analyzing the risk of failures in construction projects.
\end{abstract}

\section{Introduction}

According to the ASEAN Construction Federation (ACF) Conference in 2017, in 2016 the Association of Southeast Asian Nations (ASEAN), had a combined GDP of $\$ 2.4$ trillion. The two member nations of Malaysia and Thailand contributes $29 \%$ to the total and are currently growing at a 3-5\% growth rate. Malaysia plans to invest about US $\$ 30$ billion in construction projects, while Thailand plans on spending approximately $\$ 35$ billion [1].

This shows that the construction industry is very important for the economic and social development of the two countries. However, there is great competition within the sector that creates many obstacles and performance pressures from many factors. These factors can include but are not limited to; project time and cost overruns, as well as safety, health and environmental issues. Therefore, in addition to understanding the key success indicators, engineering managers should understand project failure indicators as well. These can help guide the analysis and prevention of future project failure.

\section{Literature review}

Over the years, researchers have studied and presented indicators of success and failure of construction projects in Thailand and Malaysia. Ogunlana et al. [2] collected data from 12 high-rise construction projects in Bangkok and found that time and cost overruns were important indicators of the potential for a projects failure.

In Malaysia, Sambasivan and Soon [3] collected responses from 150 contractors and managers and found that there were six main factors affecting a project's completion. These included time overruns, cost overruns, disputes, arbitration, litigation, and total abandonment. Toor and Ogunlana [4] inspected the perception of the key performance indicators (KPIs) in the context of large government projects in Thailand. It was found that the traditional indicator of the steel triangle (on-time, under-budget and according to specifications) are not sufficient for measuring project performance. Other performance indicators such as safety, efficient use of resources, effectiveness, satisfaction of stakeholders, and reduced conflicts and disputes are progressively becoming significant. They were suggests to considered the new measure of performance on large construction projects.

Mirza et al. [5] determined that a major contribution to unsuccessful projects is the lack of understanding or defining project and product scope at the beginning of the project. A properly defined and managed scope results in delivering a quality product, in agreed cost and within planned schedules to the stakeholders.

Nguyen et al. [6] evaluated indexes of construction project success, which included classic indicators such as project cost, project time, and project quality and safety. In addition, projects can also be evaluated by assessing technical performance, functionality, productivity, construction productivity, project stakeholders'

* Corresponding author: gomarnp $(a$,gmail.com 
satisfaction, environment, communication, and litigation evaluations, and disputes that occur during construction.

Based on the above literature, the researchers defined the concept and meaning of construction project failures as the inability to achieve time, cost, quality, and other goals as required [7]. That is to say, whenever a project does not meet the expectation of the stakeholders, the project is considered a failure [8]. Therefore, the researchers have determined that few studies have presented construction projects key failure indicators, and for those that have, the indicators are not consistent. Therefore, this research aims to analyze the indicator importance level and compare how they are different or similar as perceived by both Thai and Malaysian engineers.

\section{Research methodology}

The research instrument used for the study was a questionnaire which examined the perceptions of key failure indicators by both Thai and Malaysian engineers. The research methodology was designed as follows:

- The literature and theory were reviewed on construction project failures. These indicators are summarised in Table 1.

- Then, a detailed conceptual framework of indictors was developed from the literature review.

- From the conceptual framework, a questionnaire was designed which included six key indicators. In Part 1 of the questionnaire, there were four items related to the respondents profile regarding the country where they were employed, their position and level, experience, and gross yearly revenue of their organization (Table 2). In Part 2 of the survey, six items were used to evaluate the importance level of the respondents' opinions related to a construction project's failure. For this purpose, a five-level, Likert type agreement scale was used [9], with " 1 " indicating "the importance of that factor is very low" to " 5 " indicating "the importance of that factor is very high" as the anchor points, with " 3 " representing the response "the importance of that factor is moderate". To ensure variable and content validity, the questionnaire was evaluated by four experts in the Thai and Malaysian construction industry.

- To test the construct validity of the questionnaire, the Spearman's rank correlation coefficient was used to measure the relationship between factors. The testing results showed that all the variable were correlated indicating the construct validity of these variables [10].

- To test the reliability of the questionnaire scale, the Cronbach's alpha was used with a value from 0 to 1 , where 0 indicates the lowest reliability and 1 indicates the highest reliability. For the study, questionnaire scale reliability was calculated as 0.794 , indicating satisfactory reliability [11].

- A total of 60 questionnaires were returned from a total of 70 questionnaires sent to both Thai and Malaysian engineers, giving a highly acceptable survey response rate of $85.7 \%$ [12].
Table 1. Construction project failure indicators

\begin{tabular}{|c|c|c|c|c|c|c|}
\hline $\begin{array}{r}\begin{array}{r}\text { Project } \\
\text { failure } \\
\text { indicators }\end{array} \\
\text { References } \\
\text { and country }\end{array}$ & 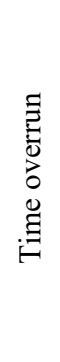 & $\begin{array}{l}\Xi \\
\Xi \\
0 \\
0 \\
0 \\
0 \\
0 \\
0 \\
0\end{array}$ & 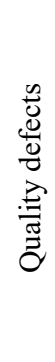 & 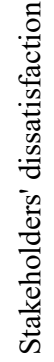 & 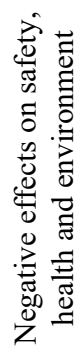 & 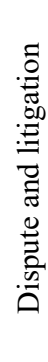 \\
\hline $\begin{array}{c}{[2]} \\
\text { Thailand }\end{array}$ & $\sqrt{ }$ & $\sqrt{ }$ & & & & \\
\hline $\begin{array}{c}{[3]} \\
\text { Malaysia }\end{array}$ & $\sqrt{ }$ & $\sqrt{ }$ & & & & $\sqrt{ }$ \\
\hline $\begin{array}{c}{[4]} \\
\text { Thailand }\end{array}$ & $\sqrt{ }$ & $\sqrt{ }$ & $\sqrt{ }$ & $\sqrt{ }$ & $\sqrt{ }$ & $\sqrt{ }$ \\
\hline $\begin{array}{c}{[5]} \\
\text { Malaysia }\end{array}$ & $\sqrt{ }$ & $\sqrt{ }$ & $\sqrt{ }$ & $\sqrt{ }$ & & \\
\hline $\begin{array}{c}{[6]} \\
\text { Thailand }\end{array}$ & $\sqrt{ }$ & $\sqrt{ }$ & $\sqrt{ }$ & $\sqrt{ }$ & $\sqrt{ }$ & $\sqrt{ }$ \\
\hline $\begin{array}{c}{[14]} \\
\text { Malaysia }\end{array}$ & $\sqrt{ }$ & $\sqrt{ }$ & $\sqrt{ }$ & & $\sqrt{ }$ & \\
\hline
\end{tabular}

- Data analysis and hypotheses testing was accomplished as follows:

1) Analysis of the importance level of the indictors comes from the following equation (1).

$$
\text { Importance level }=\frac{\text { Mean }}{\text { Standard Deviation }}
$$

2) Comparison of the perceptions between Thai and Malaysian engineers on construction project's failure indicators are presented in hypotheses $\mathrm{H}_{0}$ and $\mathrm{H}_{1}$ :

- $\mathrm{H}_{0}$ : Mean of perceptions between Thai and Malaysian engineers on construction project's failure indicators are not different.

- $\mathrm{H}_{1}$ : Mean of perceptions between Thai and Malaysian engineers on construction project's failure indicators are different.

3) A significant level $(\alpha)$ of 0.05 was used to test the hypotheses by comparing $p$-value obtained by the Mann Whitney U Test and the significant level as follows [13]:

- If p-value $<0.05, \mathrm{H}_{0}$ is rejected.

- If p-value $\geq 0.05, \mathrm{H}_{0}$ is accepted. 
Table 2. Respondents profile.

\begin{tabular}{|c|c|c|}
\hline Respondents & $\begin{array}{c}\text { Thai } \\
\text { engineer }\end{array}$ & $\begin{array}{l}\text { Malaysia } \\
\text { engineer }\end{array}$ \\
\hline Sent & 32 & 38 \\
\hline Return & 30 & 30 \\
\hline Percentage return & $93.8 \%$ & $78.9 \%$ \\
\hline \multicolumn{3}{|c|}{ Position } \\
\hline Senior engineer & $40.0 \%$ & $40.0 \%$ \\
\hline Engineer & $60.0 \%$ & $60.0 \%$ \\
\hline \multicolumn{3}{|c|}{ Experience } \\
\hline $6-10$ years & $56.7 \%$ & $60.0 \%$ \\
\hline $11-15$ years & $26.7 \%$ & $36.7 \%$ \\
\hline More than 16 years & $16.7 \%$ & $3.3 \%$ \\
\hline \multicolumn{3}{|c|}{ Average value of organization per year } \\
\hline Less than USD 10 million & $16.7 \%$ & $0.0 \%$ \\
\hline $\begin{array}{l}\text { USD } 10 \text { million to USD } \\
20 \text { million }\end{array}$ & $33.3 \%$ & $40.0 \%$ \\
\hline $\begin{array}{l}\text { USD } 20 \text { million to USD } \\
30 \text { million }\end{array}$ & $23.3 \%$ & $43.3 \%$ \\
\hline $\begin{array}{l}\text { More than USD } 30 \\
\text { million }\end{array}$ & $26.7 \%$ & $16.7 \%$ \\
\hline
\end{tabular}

\section{Data analysis results}

\subsection{Ranking of construction project's failure indicators}

The analysed ranking results of perceptions between Thai and Malaysian engineers on construction project's failure indicators are shown in Table 3 and Table 4.

Table 3 and Table 4 show that the ranking indicators influencing the failure of the construction project were the same for both Thai and Malaysian engineers except for ranked second and third (time and cost overruns importance level indices of 8.54 and 9.75 by Thai engineers, and 9.24 and 9.07 by Malaysian engineers). In fact, both of the indicators have the same linear relationship: when working time increases, cost overrun also increases.

The greatest importance in both countries was judged to be the negative effects on safety, health and the environment (importance level indices of 9.92 and 9.45 by Thai and Malaysian engineers, respectively). A possible explanation is perhaps because the operation of construction projects can be stopped if they do not comply with safety requirements, and environmental laws. Therefore, the negative effects on safety, health and the environment possibly affecting project cost, time, quality, satisfaction of stakeholders, including dispute and litigation, that most likely importance effect to the project success or failure.

Table 3. Ranking of construction projects failure indicators obtained from Thai engineers.

\begin{tabular}{|c|c|c|c|c|}
\hline Indicator & Mean & $\begin{array}{c}\text { Standard } \\
\text { deviation }\end{array}$ & $\begin{array}{c}\text { Importance } \\
\text { level }\end{array}$ & Ranking \\
\hline $\begin{array}{c}\text { Negative } \\
\text { effects on } \\
\text { safety, health } \\
\text { and } \\
\text { environment }\end{array}$ & 4.80 & 0.484 & 9.92 & 1 \\
\hline $\begin{array}{c}\text { Cost overrun } \\
\text { Time overrun }\end{array}$ & 4.67 & 0.479 & 9.75 & 2 \\
\hline $\begin{array}{c}\text { Quality } \\
\text { defects }\end{array}$ & 4.73 & 0.583 & 8.11 & 4 \\
\hline $\begin{array}{c}\text { Stakeholders' } \\
\text { dissatisfaction }\end{array}$ & 4.57 & 0.568 & 8.05 & 5 \\
\hline $\begin{array}{c}\text { Dispute and } \\
\text { litigation }\end{array}$ & 4.33 & 0.606 & 7.15 & 6 \\
\hline
\end{tabular}

Table 4. Ranking of construction projects failure indicators obtained from Malaysian engineers.

\begin{tabular}{|c|c|c|c|c|}
\hline Indicator & Mean & $\begin{array}{c}\text { Standard } \\
\text { deviation }\end{array}$ & $\begin{array}{c}\text { Importance } \\
\text { level }\end{array}$ & Ranking \\
\hline $\begin{array}{c}\text { Negative } \\
\text { effects on } \\
\text { safety, health } \\
\text { and } \\
\text { environment }\end{array}$ & 4.63 & 0.490 & 9.45 & 1 \\
\hline $\begin{array}{c}\text { Time overrun } \\
\text { Cost overrun }\end{array}$ & 4.60 & 0.498 & 9.24 & 2 \\
\hline $\begin{array}{c}\text { Quality } \\
\text { defects }\end{array}$ & 4.53 & 0.507 & 8.93 & 4 \\
\hline $\begin{array}{c}\text { Stakeholders' } \\
\text { dissatisfaction }\end{array}$ & 4.43 & 0.504 & 8.79 & 5 \\
\hline $\begin{array}{c}\text { Dispute and } \\
\text { litigation }\end{array}$ & 4.30 & 0.651 & 6.61 & 6 \\
\hline
\end{tabular}

\subsection{Mann Whitney Testing}

Table 5 presents the results of the perceptions between Thai and Malaysian engineers on construction projects' failure indicators. 
Table 5. Hypotheses testing results.

\begin{tabular}{|c|c|c|}
\hline Indicator & p-value* & $\begin{array}{c}\text { Hypotheses } \\
\text { testing results }\end{array}$ \\
\hline Time overrun & 0.312 & Not different \\
\hline Cost overrun & 0.217 & Not different \\
\hline Quality defects & 0.081 & Not different \\
\hline $\begin{array}{c}\text { Stakeholders' dissatisfaction } \\
\text { Negative effects on safety, } \\
\text { health and environment }\end{array}$ & 0.170 & Not different \\
\hline Dispute and litigation & 0.419 & Not different \\
\hline
\end{tabular}

*When $\mathrm{p}$-value $\geq 0.05, \mathrm{H}_{0}$ is accepted.

Table 5 also showed the hypotheses testing results after p-value analysis. These results indicated that the six indicators influencing the perceived failure of Thai and Malaysian engineers were significantly similar. The possible reason why all indicators in perceived both Thai and Malaysian engineers are similarly is that all those indicators are considered as important on project performance in the construction industry of both countries. In addition, over the past years the stakeholders in the construction industry of both countries are almost focused on safety, health and environment as a first priority along with cost, time, quality and other indicators. Therefore, a combined analysis was also done to find the weight of the indicators. These are shown in Table 6.

Table 6. Importance weights of construction project's failure indicators after a combined analysis.

\begin{tabular}{|c|c|}
\hline Indicator & $\begin{array}{c}\text { Importance weights } \\
\mathbf{( \% )}\end{array}$ \\
\hline Time overrun & $17.41 \%$ \\
\hline Cost overrun & $18.44 \%$ \\
\hline Quality defects & $16.43 \%$ \\
\hline $\begin{array}{c}\text { Stakeholders' dissatisfaction } \\
\text { Negative effects on safety, } \\
\text { health and environment }\end{array}$ & $15.36 \%$ \\
\hline Dispute and litigation & $18.83 \%$ \\
\hline
\end{tabular}

\section{Conclusion}

The purpose of this research was to compare the ranking and significance of failure indicators with the Thai and Malaysian construction industry. From the questionnaire and the subsequent analysis, the results were ranked as follows (most important to least important as weights of percentage): 1) negative effects on safety, health and environment, 2) cost overrun, 3) time overrun, 4) quality defects, 5) stakeholders' dissatisfaction, and 6) dispute and litigation.

Analysis by use of the Mann Whitney U Test also determined that the perception differences between engineers in their respective countries was also small. However, the negative effects on safety, health and environment had the highest priority (9.92) on Thai engineer perceptions, while with Malaysian engineers it was slightly smaller at 9.45 . This is probable because project construction safety, health and environmental issues directly and indirectly affect other project failure indicators. For example, when an accident occurs, the project is most likely to experience a delay in the schedule, budget overruns, stakeholders' dissatisfaction, and possibly dispute and litigation at the end.

Therefore, to avoid the project failure, "safety should be job one". Also, there should be a heightened awareness amongst all parties and managers about the indicators and how to avoid them if possible. In the future research may studies in different countries and regions to compare the rank and importance level of failure indicators.

\section{References}

1. Prachachat Business News, Retrieved at: https://tinyurl.com/y8bdaxol (2018 Feb 1)

2. S.O. Ogunlana, K. Promkuntong, V. Jearkjirm, Int. J. Proj. Manag. 14 (1), 37-45 (1996)

3. M. Sambasivan, Y.W. Soon, Int. J. Proj. Manag. 25 (5), 517-526 (2007)

4. S. Toor, S.O. Ogunlana, Int. J. Proj. Manag. 28 (3), 228-236 (2010)

5. M.N. Mirza, Z. Pourzolfaghar, N. Shahnazari, Procedia Technology. 9, 722-729 (2013)

6. T.A. Nguyen, V. Chovichien, S. Takano, Int. J. Const. Eng. Manag. 2 (3), 70-84 (2013)

7. A.O. Gwaya, S.M. Masu, G. Wanyona, Int. J. Soft. Comp. Eng. 4 (1), 64-69 (2014)

8. O.P. Kharbanda, J.K. Pinto, What Made Gertie Gallop: Learning from Project Failure (London: Chapman and Hall, 1996)

9. R. Likert, Social psychology: Experimentation, theory, research (Intext, Scranton, PA, 1972)

10. J. Nunnally, Psychometric theory (McGraw-Hill. New York, 1967)

11. SPSS Training Department, Survey research using SPSS. (SPSS, Inc., Chicago, 1998)

12. E. Babbie, The practice of social research, 5th Ed.(Wadsworth Publishing, Belmont, CA, 1989)

13. T. Harris, J.W. Hardin, StataJournal 13, 337-343 (2013)

14. B. Xiong, M. Skitmore, B. Xia, M.A. Masrom, K. Ye, A. Bridge, Int. J. Proj. Manag. 32, 482-491 (2014) 